Article

\title{
Biological and Chemical Diversity of Bacteria Associated with a Marine Flatworm
}

\author{
Hui-Na Lin ${ }^{1,2,+}$, Kai-Ling Wang ${ }^{1,3,+}$ iD , Ze-Hong Wu ${ }^{4,5}$, Ren-Mao Tian ${ }^{6}$, Guo-Zhu Liu ${ }^{7}$ \\ and Ying $\mathrm{Xu}^{1, *}$ id \\ 1 Shenzhen Key Laboratory of Marine Bioresource \& Eco-Environmental Science, \\ Shenzhen Engineering Laboratory for Marine Algal Biotechnology, College of Life Sciences and Oceanography, \\ Shenzhen University, Shenzhen 518060, China; timaroona@163.com (H.-N.L.); kailingw@163.com (K.-L.W.) \\ 2 School of Life Sciences, Xiamen University, Xiamen 361102, China \\ 3 Key Laboratory of Marine Drugs, Ministry of Education of China, School of Medicine and Pharmacy, \\ Ocean University of China, Qingdao 266003, China \\ 4 The Eighth Affiliated Hospital, Sun Yat-sen University, Shenzhen 518033, China; wuzehong922@126.com \\ 5 Integrated Chinese and Western Medicine Postdoctoral Research Station, Jinan University, \\ Guangzhou 510632, China \\ 6 Division of Life Science, The Hong Kong University of Science and Technology, Clear Water Bay, Kowloon, \\ Hong Kong SAR, China; tianrenmao@gmail.com \\ 7 HEC Research and Development Center, HEC Pharm Group, Dongguan 523871, China; \\ liuguozhu@hecpharm.com \\ * Correspondence: boxuying@szu.edu.cn; Tel.: +86-755-26958849; Fax: +86-755-26534274 \\ $\dagger$ These authors contributed equally to this work.
}

Received: 20 July 2017; Accepted: 29 August 2017; Published: 1 September 2017

\begin{abstract}
The aim of this research is to explore the biological and chemical diversity of bacteria associated with a marine flatworm Paraplanocera sp., and to discover the bioactive metabolites from culturable strains. A total of 141 strains of bacteria including 45 strains of actinomycetes and 96 strains of other bacteria were isolated, identified and fermented on a small scale. Bioactive screening (antibacterial and cytotoxic activities) and chemical screening (ultra-performance liquid chromatography-mass spectrometry (UPLC-MS)) yielded several target bacterial strains. Among these strains, the ethyl acetate (EA) crude extract of Streptomyces sp. XY-FW47 fermentation broth showed strong antibacterial activity against methicillin-resistant Staphylococcus aureus ATCC43300 (MRSA ATCC43300) and potent cytotoxic effects on HeLa cells. The UPLC-MS spectral analysis of the crude extract indicated that the strain XY-FW47 could produce a series of geldanamycins (GMs). One new geldanamycin (GM) analog, 4,5-dihydro-17-O-demethylgeldanamycin (1), and three known GMs (2-4) were obtained. All of these compounds were tested for antibacterial, cytotoxic, and antifungal activities, yet only GM (3) showed potent cytotoxic (HeLa cells, $\mathrm{EC}_{50}=1.12 \mu \mathrm{g} / \mathrm{mL}$ ) and antifungal (Setosphaeria turcica MIC $=2.40 \mu \mathrm{g} / \mathrm{mL}$ ) activities. Their structure-activity relationship (SAR) was also preliminarily discussed in this study.
\end{abstract}

Keywords: marine flatworm; natural products; bacteria; Paraplanocera sp.; Streptomyces sp.; geldanamycin

\section{Introduction}

Flatworms are invertebrates that belong to Platyhelminthes. About 4500 species of flatworms have been reported, of which over 1000 species are exclusively marine flatworms primarily belonging to Turbellaria polyclad [1]. Marine flatworms are $3-20 \mathrm{~cm}$ in length but some are quite small. Most marine flatworms are free-living organisms and they are found to hide under rocks or inside empty shells in the 
daytime. In recent years, flatworms have attracted broad research interests worldwide. Several studies on the reproductive system of flatworms provided useful information for research on stem cells [2], ageing [3] and bioadhesion [4]. Recent reports showed that flatworms are suitable models for probing environmental changes, such as salinity stress [5] and oxygen concentrations variations [6].

Chemical defense is popular among marine invertebrates [7], such as sponges, corals and sea hares. In many cases, chemical weapons are produced by microorganisms associated with their invertebrate hosts [8-10]. Marine flatworms may also adopt chemical defense to protect themselves. Indeed, the deadly toxin tetrodotoxin (TTX) has been detected in marine flatworm Planocera sp. [11] and further investigation of Planocera multitentaculata indicated that a high concentration of TTX existed in the genitalia, digestive organs and other tissues [12]. There is doubt that TTX and its analogs might be produced by the endogenous/symbiotic bacteria of these flatworms [13]. Unfortunately, only a handful studies [14-17] have been carried out to investigate the microorganisms associated with flatworms. Gruber-Vodicka et al. [14] discovered the symbiotic relationship between Paracatenula galateia and an uncultured sulfur-oxidizing Alphaproteobacteria strain. Xu et al. [15], Zhang et al. [16] and Lin et al. [17] described the identification of new bacteria species isolated from a marine flatworm Paraplanocera sp. Since Acoelomorpha flatworms had been excluded from Platyhelminthes to be an independent phylum [18], the symbiotic relationship and chemical defense between algae and Acoelomorpha flatworms will not be discussed in this study. Therefore, it will be of interest to investigate the bacteria associated with marine flatworms, which may provide more clues to understand their chemical defensive system. Geldanamycin (GM), firstly reported by Deboer et al. [19], was discovered from Streptomyces hygroscopicus. This compound belongs to the benzoquinone ansamycin family possessing a 19-membered macrocyclic lactam. The biosynthesis of GM and its analogs requires polyketide synthase (PKS) genes. GM is an antibiotic with potent anticancer, antibacterial, anti-protozoa and antifungal activities. However, its hepatotoxicity and poor water solubility limit the therapeutic efficiency of GM. Therefore, studies on GM analogs have now gained increasing attention. Accordingly, various GM analogs have been developed by chemical modification and by engineered biosynthesis [20]. Especially, GM and its two semi-synthetic analogs 17-allylaminogeldanamycin (17-AAG) and 17-dimethylaminoethylamino-17-demethoxygeldanamyein (17-DMAG) show a broad spectrum of anticancer activity by inhibiting Hsp90 (Heat shock protein 90) activity [21,22]. Although both 17-AAG and 17-DMAG were used in clinical trials, they failed in phase II and I clinical trials, due to their severe hepatotoxicity, low aqueous solubility and limited oral bioavailability [23]. By now, only a few of natural GM analogs have been discovered from Streptomyces hygroscopicus and other Streptomyces sp. [24-26]. Hence, discovering natural and potent geldanamycins (GMs) with excellent bioactivities without causing the above common problems will be meaningful for the development of anticancer candidates.

In this study, we isolated and identified the bacteria from a marine flatworm Paraplanocera sp., conducted bioactive (activity against Methicillin-Resistant Staphylococcus aureus (MRSA) ATCC43300 and cytotoxic effects on HeLa cells) and chemical (ultra-performance liquid chromatography-mass spectrometry (UPLC-MS)) diversity screening with the ethyl acetate (EA) crude extracts of the cultured bacteria, and performed further isolation, structure elucidation, and bioactive evaluation for the obtained metabolites of the target strains. One novel GM analog 4,5-dihydro-17-O-demethylgeldanamycin (1) and three known GMs (2-4) were isolated from the fermentation broth of XY-FW47 (see Figure 1). All of these compounds were tested for anti-MRSA ATCC43300, cytotoxic, and antifungal activities, and their structure-activity relationship (SAR) was also preliminarily discussed. This is the first report on studying biodiversity and chemical diversity of bacteria associated with marine flatworms, which calls more attention to exploit the biological and chemical potential of marine flatworms. 


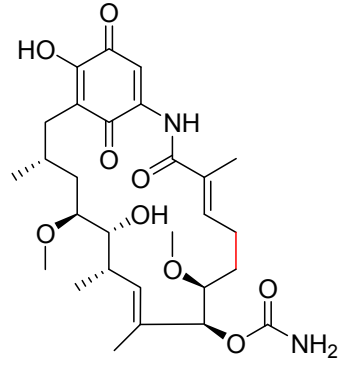

1

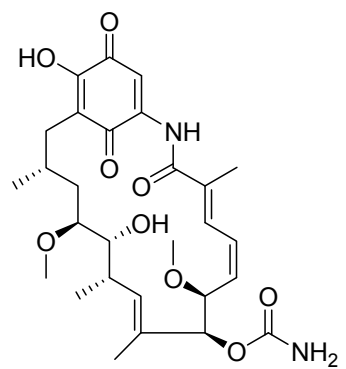

2

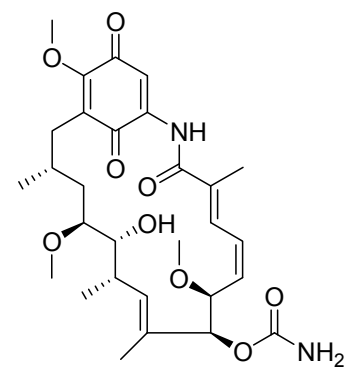

3

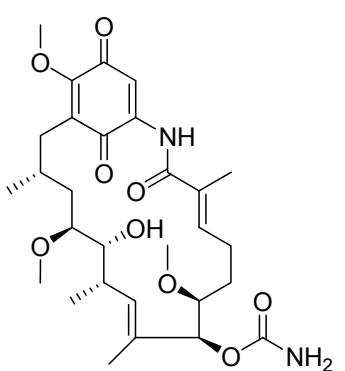

4

Figure 1. Chemical structures of geldanamycin and its analogs.

\section{Results and Discussion}

\subsection{Sample Identification}

A marine flatworm (Figure 2), collected at depth between 1 and $3 \mathrm{~m}$ in the intertidal zone of Yung Shue O, Hong Kong $\left(114^{\circ} 21^{\prime}\right.$ E, $\left.22^{\circ} 24^{\prime} \mathrm{N}\right)$ in January 2014, was originally identified as Stylochus sp. by a simple morphological comparison, but was later identified to be Paraplanocera sp. based on its $18 \mathrm{~S}$ rRNA gene sequence (1260 bp). Maximum likelihood tree (Figure 3) shows the phylogenetic position of the Paraplanocera sp. which is affiliated to the superfamily of Stylochoidea and forms the closest genetic distance with Paraplanocera oligoglena. The GenBank accession number for the 18S rRNA gene sequence of Paraplanocera sp. is MF319765.

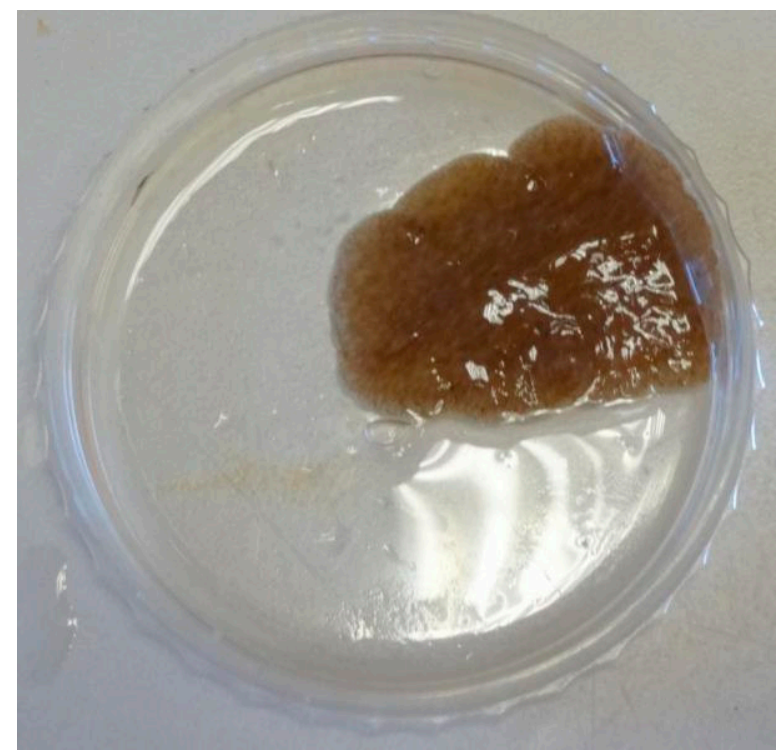

Figure 2. Photo of the Paraplanocera sp. used in this study. 


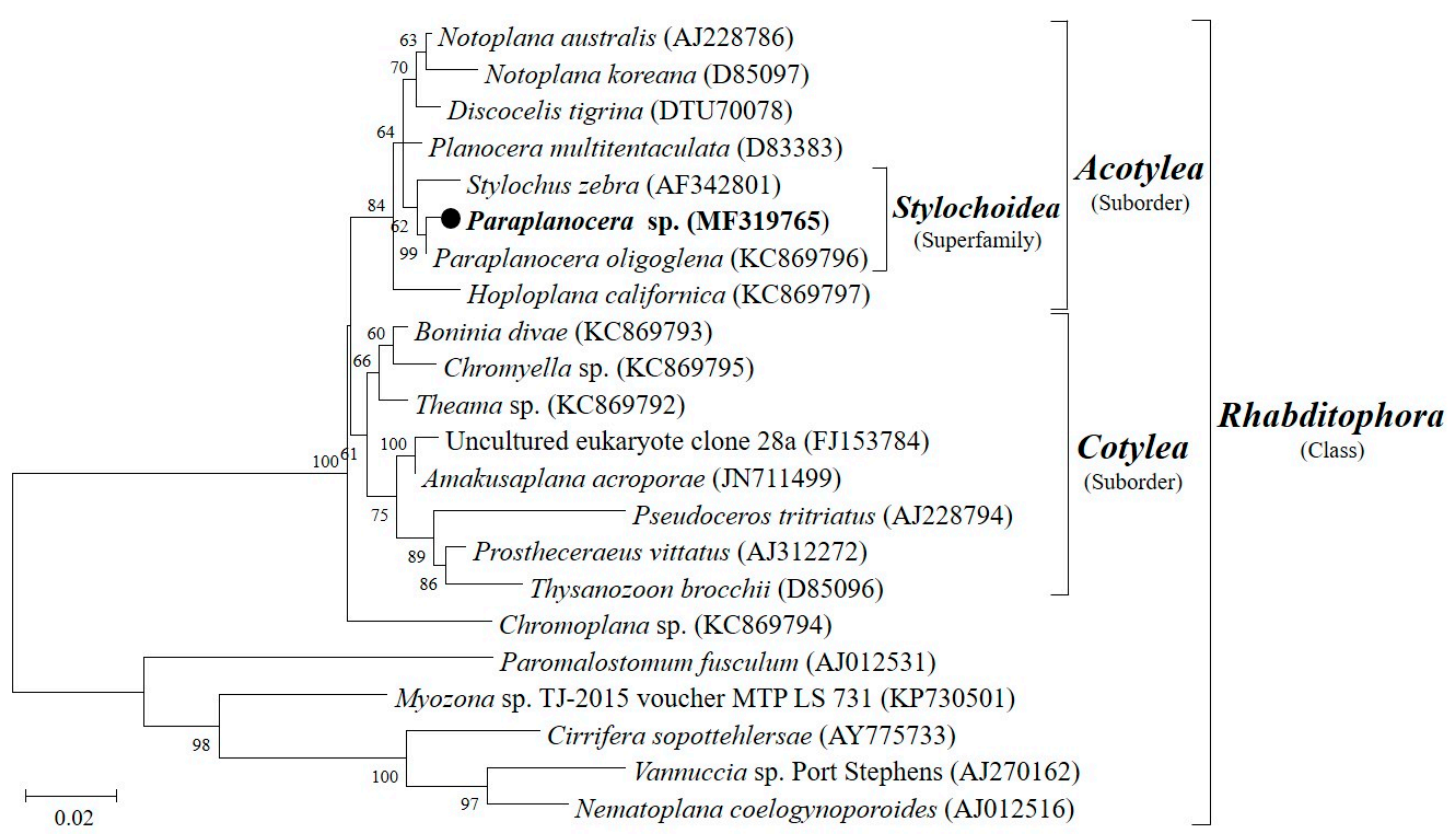

Figure 3. Maximum likelihood tree showing the phylogenetic position of the Paraplanocera sp. based on the $18 \mathrm{~S}$ rRNA gene (1260 bp).

\subsection{Isolation and Taxonomy of Bacteria from the Marine Flatworm Paraplanocera sp.}

A total of 141 strains of bacteria associated with the marine flatworm Paraplanocera sp. were isolated and identified, including 37 species of actinobacteria belonging to nine genera and 64 species of non-actinobacteria affiliating to 27 genera (the information of the isolates are detailed in Table 1). The 16S rRNA genes of all the cultured isolates have high similarity $(98.5-100 \%)$ with their reference strains except the three novel species (marked in bold in Table 1). There were 45 strains of actinomycetes listed as follows, Streptomyces (14 strains of 13 species), Micromonospora (12 strains of eight species), Mycobacterium (nine strains of eight species), Tsukamurella (two strains of two species), Microbacterium (two strains of two species), Micrococcus (two strains of one species), Pseudonocardia (two strains of one species), Brevibacterium and Arthrobacter. There were 96 strains of non-actinomycetes, including Bacillus (33 strains of 22 species), Vibrio (11 strains of six species), Halobacillus (six strains of five species), Microbulbifer (four strains of three species), Ruegeria (11 strains of two species), Pseudovibrio (five strains of three species), Fictibacillus (two strains of two species), Pseudoalteromonas (two strains of one species), Photobacterium, Joostella (two strains of one species), Flammeovirga (two strains of one species), Arcobacter, Staphylococcus, Aquimarina, Tenacibaculum, Roseovarius, Cupriavidus, Oceanobacillus, Deinococcus, Pseudomonas, Paenibacillus, Stenotrophomonas, Paracoccus, Psychrobacillus, Alcaligenes (two strains of two species), Roseivirga and Methylobacterium. These results showed a great diversity of culturable bacteria associated with marine flatworm Paraplanocera sp.

Three novel bacterial strains were discovered from this study. Two strains, UST20140214-052 and UST20140214-015B, had been characterized to be new species of the genus Pseudovibrio and published elsewhere $[15,16]$. In these years, there is a growing interest in Pseudovibrio species as more and more isolates have been identified from sponges, corals, and sea squirts and, among them, some strains have genomic interactions with host marine invertebrates and gene clusters for producing secondary metabolites to protect the host from pathogens [27]. Another new species strain, XY-FW106, was characterized to be Deinococcus planocerae [17]. Interestingly, XY-FW106 showed resistance against ultraviolet irradiation [28], which might provide some protective function for the survival of the host flatworm, which lived in the shallow waters. 
Table 1. The diversity of the culturable bacteria derived from the marine flatworm Paraplanocera sp. A total of 141 strains of bacteria, including 37 species of actinobacteria and 64 species of non-actinobacteria, were identified by comparison $16 \mathrm{~S}$ rDNA sequences of the isolates with their reference strains in the GeneBank of NCBI. All the known isolates have high identity percentage values with 98.5-100\% except the three new species (Pseudovibrio hongkongenesis UST20140214-015B [15], Pseudovibrio stylochi UST20140214-052 [16], and Deinococcus planocerae XY-FW106 [17]).

\begin{tabular}{|c|c|c|c|c|c|c|}
\hline & Species & Isolate ID & $\begin{array}{l}\text { Accession Number of the } \\
\text { Most Similar Strain }\end{array}$ & Species & Isolate ID & $\begin{array}{l}\text { Accession Number of the } \\
\text { Most Similar Strain }\end{array}$ \\
\hline \multirow{22}{*}{ Actinobacteria } & Streptomyces libani & XY-FW38 & JN180219 & Mycobacterium pallens & XY-FW60 & KF378757 \\
\hline & S. rutgersensis & XY-FW46 & FJ99174 & M. parafortuitum & XY-FW63 & NZ_MVID01000062 \\
\hline & S. samsunensis & XY-FW47 & MF664376 & M. peregrinum & XY-FW64 & AF537362 \\
\hline & S. sudanensis & XY-FW121 & EF515876 & M. kumamotonense & XY-FW71 & AB239925 \\
\hline & S. tendae & XY-FW57W & D63873 & M. poriferae & XY-FW80 & JN627174 \\
\hline & S. luridus & XY-FW100W & AB184150 & M. chubuense & XY-FW83 & JYNX01000034 \\
\hline & S. alboflavus & XY-FW107 & JNXT01000131 & M. bacteremicum & XY-FW90 & FJ172308 \\
\hline & S. cirratus & XY-FW109 & AY999794 & & XY-FW62 & HQ009482 \\
\hline & S. paroulus & XY-FW120 & AB184326 & M. iranicum & XY-FW77 & HQ009482 \\
\hline & S. bacillaris & XY-FW137 & AB184439 & Microbacterium & & \\
\hline & S. cavourensis & XY-FW153 & AB184264 & saperdae & XY-FW102 & AB004719 \\
\hline & S. daliensis & XY-FW154 & AY785161 & M. resistens & XY-FW145 & BCRA01000173 \\
\hline & S. phytohabitans & $\begin{array}{l}\text { XY-FW134 } \\
\text { XY-FW142 }\end{array}$ & $\begin{array}{l}\text { JQ345722 } \\
\text { IO345722 }\end{array}$ & $\begin{array}{l}\text { Tsukamurella } \\
\text { turosinoselzeens }\end{array}$ & XY-FW86 & FJ643549 \\
\hline & \multirow{9}{*}{$\begin{array}{l}\text { Micromonospora eburnea } \\
\text { M. schwarzwaldensis } \\
\text { M. carbonacea } \\
\text { M. tulbaghiae } \\
\text { M. echinospora } \\
\text { M. marina } \\
\text { M. wenchangensis } \\
\text { M. aurantiaca }\end{array}$} & XY-FW94 & AB107231 & T. strandjordii & XY-FW101 & AF283283 \\
\hline & & XY-FW95 & КС517406 & Brevibacterium iodinum & XY-FW82 & X76567 \\
\hline & & XY-FW99 & KM370042 & Micrococcus & XY-FW48A & FJ214355 \\
\hline & & XY-FW123 & EU196562 & yunnanensis & XY-FW75 & FJ214355 \\
\hline & & XY-FW130 & KY818670 & Arthrobacter soli & XY-FW120A & EF660748 \\
\hline & & XY-FW132 & KM370074 & Pseudonocardia & XY-FW148 & EF114314 \\
\hline & & $\begin{array}{l}\text { XY-FW65 } \\
\text { XY-FW69 }\end{array}$ & $\begin{array}{l}\text { JQ768361 } \\
\text { CP002162 }\end{array}$ & carboxydivorans & XY-FW149 & EF114314 \\
\hline & & XY-FW97 & СР002162 & & & \\
\hline & & XY-FW122 & СР002162 & & & \\
\hline \multirow{10}{*}{ Non-actinobacteria } & Bacillus lehensis & XY-FW24 & KX082867 & M. variabilis & XY-FW48B & KP640585 \\
\hline & B. pumilus & XY-FW37 & AF492815 & & XY-FW54 & KP640585 \\
\hline & B. qibsonii & XY-FW43 & KM036072 & Ruegeria arenilitoris & XY-FW31 & JQ807219 \\
\hline & B. aerius & XY-FW50 & KY243945 & & XY-FW32 & JQ807219 \\
\hline & B. berkeleyi & XY-FW53 & KR476448 & & XY-FW40 & JQ807219 \\
\hline & B. algicola & XY-FW55 & KY580789 & & XY-FW45 & JQ807219 \\
\hline & B. altitudinis & XY-FW66 & ASJC01000029 & & XY-FW58 & JQ807219 \\
\hline & \multirow[t]{2}{*}{ B. amyloliquefaciens subsp. plntruim } & XY-FW105 & FN597644 & & XY-FW72 & JQ807219 \\
\hline & & & & & XY-FW96 & JQ807219 \\
\hline & B. aerophilus & XY-FW112 & KX951942 & & XY-FW138 & JQ807219 \\
\hline
\end{tabular}


Table 1. Cont.

\begin{tabular}{|c|c|c|c|c|c|c|}
\hline & Species & Isolate ID & $\begin{array}{l}\text { Accession Number of the } \\
\text { Most Similar Strain }\end{array}$ & Species & Isolate ID & $\begin{array}{l}\text { Accession Number of the } \\
\text { Most Similar Strain }\end{array}$ \\
\hline \multirow{27}{*}{ Non-actinobacteria } & B. flecus & XY-FW125 & NZ_JANV01000041 & \multirow{2}{*}{$\begin{array}{l}\text { Pseudovibrio } \\
\text { hongkongenesis } \\
{[15]}\end{array}$} & \multirow[t]{2}{*}{ UST20140214-015B } & \multirow[t]{2}{*}{ KP207599 } \\
\hline & B. invictus & XY-FW131 & KF060662 & & & \\
\hline & B. megaterium & XY-FW1A & MF597792 & P. stylochi [16] & UST20140214-052 & KР207600 \\
\hline & \multirow[t]{3}{*}{ B. aquimaris } & XY-FW5 & MF429570 & \multirow{3}{*}{ P. ascidiaceicola } & XY-FW21B & LN812993 \\
\hline & & XY-FW23 & KY777466 & & XY-FW51 & LN812993 \\
\hline & & XY-FW49 & KY753251 & & XY-FW57 & LN812993 \\
\hline & \multirow[t]{2}{*}{ B. marisflavi } & XY-FW30 & MF062965 & \multirow{5}{*}{$\begin{array}{l}\text { Fictibacillus barbaricus } \\
\text { F. phosphorivorans } \\
\text { Photobacterium } \\
\text { swingsii } \\
\text { Arcobacter nitrofigilis } \\
\text { Staphylococcus } \\
\text { epidermidis }\end{array}$} & XY-FW78 & KY436215 \\
\hline & & XY-F W59 & MF062965 & & XY-FW42 & KY471632 \\
\hline & \multirow[t]{2}{*}{ B. aryabhattai } & XY-FW110 & EF114313 & & XY-FW3 & KY229808 \\
\hline & & XY-FW117 & EF114313 & & XY-FW17 & EU106662 \\
\hline & \multirow[t]{4}{*}{ B. nealsonii } & XY-FW116 & EU656111 & & XY-FW21A & MF429388 \\
\hline & & XY-FW126 & EU656111 & Aquimarina mueller & XY-FW21C & AY608408 \\
\hline & & XY-FW133 & EU656111 & Tenacibaculum aiptasiae & XY-FW28 & КC178948 \\
\hline & & XY-FW139 & EU656111 & \multirow{14}{*}{$\begin{array}{l}\text { Roseovarius aestuarii } \\
\text { Cupriavidus } \\
\text { campinensis } \\
\text { Oceanobacillus picturae } \\
\text { Deinococcus } \\
\text { planocerae [17] } \\
\text { Pseudomonas libanensis } \\
\text { Paenibacillus cineris } \\
\text { Stenotrophomonas } \\
\text { rhizophila } \\
\text { Paracoccus honmiensis } \\
\text { Alcaligenes aquatilis } \\
\text { subsp. phenolicus }\end{array}$} & XY-FW56 & EU156066 \\
\hline & \multirow[t]{4}{*}{ B. idriensis } & XY-FW113 & AY904033 & & XY-FW67 & KY010351 \\
\hline & & XY-FW115 & AY904033 & & XY-FW73 & KX068643 \\
\hline & & XY-FW118 & AY904033 & & XY-FW106 & КT886059 \\
\hline & & $\begin{array}{l}\text { XY-FW129 } \\
\text { XY-FW136 }\end{array}$ & $\begin{array}{l}\text { AY904033 } \\
\text { AY904033 }\end{array}$ & & $\begin{array}{l}\text { XY-FW111 } \\
\text { XY-FW114 }\end{array}$ & $\begin{array}{l}\text { KY933473 } \\
\text { AJ575658 }\end{array}$ \\
\hline & Vibrio cyclitrophicus & XY-FW7B & KY382786 & & XY-FW119 & СР007597 \\
\hline & V. chagasii & XY-FW19 & LN832958 & & XY-FW124 & DQ342239 \\
\hline & H. locisalis & XY-FW34A & JQ799098 & & XY-FW141 & JX986974 \\
\hline & H. halophilus & XY-FW34B & KX507262 & & XY-FW146 & AUBT01000026 \\
\hline & H. trueperi & XY-FW68 & LT635432 & & & \\
\hline & \multirow{2}{*}{ H. alkaliphilus } & XY-FW10 & NZ_FOOG01000089 & & & \\
\hline & & XY-FW16 & NZ_FOOG01000089 & & & \\
\hline & Microbulbifer elongates & XY-FW27 & KY176867 & & & \\
\hline & M. epialgicus & XY-FW39 & KT758460 & & & \\
\hline
\end{tabular}




\subsection{The Bioactive and UPLC-MS Chemical Screening of the Isolated Bacteria}

All 141 bacterial isolates were fermented on a small scale and the EA crude extracts of their bacterial fermentation broth were evaluated for anti-MRSA (strain ATCC43300) and cytotoxic (HeLa cells) activities. In total, eight extracts showed anti-MRSA activity and seven showed cytotoxic activity. Among them, extracts of strains XY-FW47 and XY-FW120 showed both potent antibacterial and cytotoxic activities. Four strains of Streptomyces showed the strongest anti-MRSA activity. In addition, one Arthrobacter soli strain and one Bacillus siamensis strain showed moderate activity against MRSA, and the latter strain also showed weak effects on HeLa cells (Tables 2 and 3). Two strains of Streptomyces revealed high activity against HeLa cells, while two other Streptomyces strains and one Paracoccus strain showed moderate activity against HeLa cells (Table 3). These results suggested that the bacteria associated with the marine flatworms might be a rich source of bioactive compounds. In this study, the strains of XY-FW47 and XY-FW120 were selected as the target strains for further chemical characterization due to their strongest bioactivities.

Table 2. The antibacterial activity against methicillin-resistant Staphylococcus aureus ATCC43300 (MRSA ATCC43300) of the bacteria associated with Paraplanocera sp.

\begin{tabular}{ccc}
\hline \multicolumn{2}{c}{ Bacteria Associated with Paraplanocera sp. } & Tested Pathogen \\
\hline Isolate ID & Closest Described Species & MRSA ATCC43300 \\
\hline XY-FW47 & Streptomyces samsunensis & +++ \\
XY-FW142 & Streptomyces phytohabitans & +++ \\
XY-FW153 & Streptomyces cavourensis & +++ \\
XY-FW120 & Streptomyces parvulus & +++ \\
XY-FW120A & Arthrobacter soli & ++ \\
XY-FW105 & Bacillus siamensis & ++ \\
XY-FW56 & Roseovarius aestuarii & + \\
XY-FW48A & Micrococcus yunnanensis & + \\
\hline
\end{tabular}

Final sample concentration: $100 \mu \mathrm{g} / \mathrm{mL} ;+$ represents weak activity $(0.2<\mathrm{OD} \leq 0.4) ;++$ represents moderate activity $(0.1<\mathrm{OD} \leq 0.2)$; +++ represents high activity $(0.05<\mathrm{OD} \leq 0.1)$; Negative control with $\mathrm{DMSO}(\mathrm{OD} \approx 0.8)$; Positive control with vancomycin $(\mathrm{OD} \approx 0.05)$.

Table 3. The cytotoxic activity of the bacteria associated with Paraplanocera sp.

\begin{tabular}{ccc}
\hline \multicolumn{2}{c}{ Bacteria Associated with Paraplanocera sp. } & Cell Line \\
\hline Isolate ID & Closest Described Species & HeLa Cell \\
XY-FW47 & Streptomyces samsunensis & +++ \\
XY-FW120 & Streptomyces parvulus & +++ \\
XY-FW142 & Streptomyces phytohabitans & ++ \\
XY-FW153 & Streptomyces cavourensis & ++ \\
XY-FW124 & Paracoccus honmiensis & ++ \\
XY-FW105 & Bacillus siamensis & + \\
XY-FW100W & Streptomyces luridus & + \\
\hline
\end{tabular}

Final sample concentration: $100 \mu \mathrm{g} / \mathrm{mL} ;+$ represents weak activity $(0.2<\mathrm{OD} \leq 0.4)$; ++ represents moderate activity $(0.1<\mathrm{OD} \leq 0.2)$; +++ represents high activity $(0.05<\mathrm{OD} \leq 0.1)$; Negative control with $\mathrm{DMSO}(\mathrm{OD} \approx 0.8)$.

Further chemical analyses on the two strains of Streptomyces (XY-FW120 and XY-FW47) were proceeded by UPLC-MS on a reversed phase $\mathrm{C} 18$ column with a gradient solution $\mathrm{ACN} / \mathrm{H}_{2} \mathrm{O}(5-95 \%$, $25 \mathrm{~min}$ ). As shown in Figure 4, XY-FW120 produced a main metabolite with a characteristic ultraviolet (UV) absorption of $430-440 \mathrm{~nm}$ and a high resolution electrospray ionization mass spectroscopy (HR-ESI-MS) $[\mathrm{M}+\mathrm{H}]^{+}$of 1255.6924. Combined database searching (Dictionary of natural products, SciFinder, AntiBase, MarinLit, etc.) with extensive literature searching suggested this metabolite was very likely to be actinomycin D (see Figure 4 and Figure S9) which had already been described by Meienhofer and Atherton [29]. As actinomycin D is a well-known antibiotic with antitumor activity, 
this also explains why the extract of XY-FW120 showed strong activity in both bioassays. It was also reported that the same species Streptomyces parvulus DAUFPE 3124 produced only actinomycin D [30]. However, the strain XY-FW120 produced not only a high level of actinomycin D, but also a few known actinomycin D analogs with trace amounts (data not shown). As the UV absorption patterns as well as the high resolution mass data of these actinomycin compounds were the same as those described in the literature, there is a very high chance that these compounds are exactly the same as those reported. However, there might be one case that our consumption could be wrong: enantiomers are also possible, although the odds are low. Based on these analyses, the metabolites of strain XY-FW120 are almost fully understood, thus we did not proceed for further investigation on this strain to characterize its metabolites.

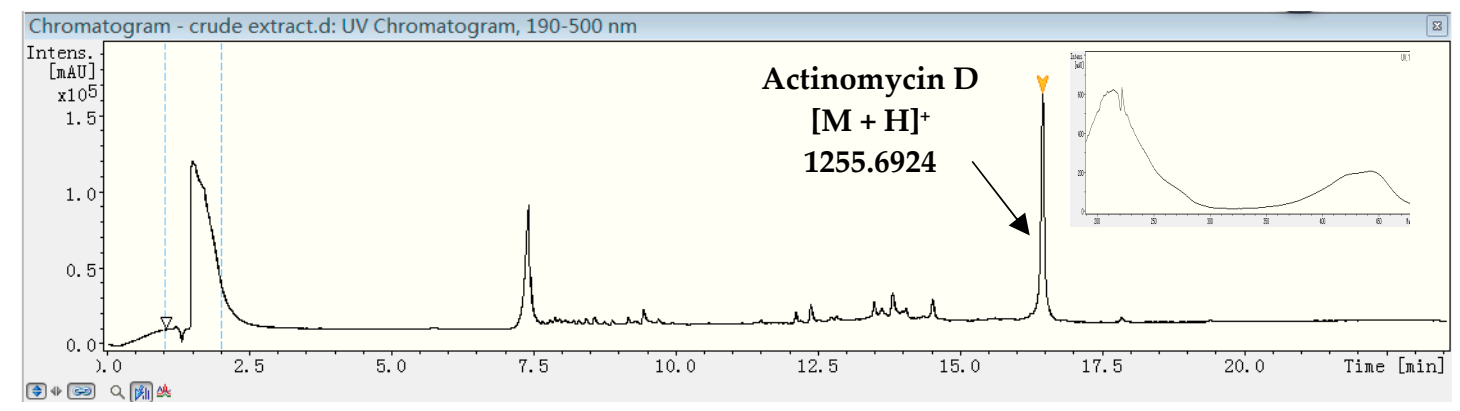

Figure 4. Ultra-performance liquid chromatography-mass spectrometry (UPLC-MS) analysis and ultraviolet (UV) spectra of the crude extract of XY-FW120. The main metabolite produced by XY-FW120 is actinomycin D.

HPLC analysis of the metabolites of XY-FW47, which was closely related to Streptomyces samsunensis $\mathrm{M} 1463^{\mathrm{T}}$ [31], indicated a series of compounds with very similar UV absorption patterns. All of these compounds all had characteristic UV absorption at $305 \mathrm{~nm}$ with their HR-ESI-MS [M - H] ${ }^{-}$ ranging from 533.2987 to 561.2936 (see Figure 5). Combined database searching with extensive literature searching based on these spectroscopic data, led us to conclude that these compounds with HR-ESI-MS [M - H] ${ }^{-}$559.2778, 545.2548 and 561.2936 were GM, 17-O-demethylgeldanamycin and 4,5-dihydrogeldanamycin, respectively $[19,32,33]$. GM, previously isolated from Streptomyces hygroscopicus, is a benzoquinone antibiotic containing the typical structures of benzoquinone and dienamide. This class of compounds showed various bioactivities, including anticancer, anti-protozoa, antimalarial and antifungal activities $[34,35]$. Based on extensive investigation of the literatures and the analyses of UPLC-MS data, it is concluded that these compounds with HR-ESI-MS [M - H] ${ }^{-} 547.2805$ (retention time at $8.0 \mathrm{~min}$ ), 533.2992 and 547.2636 (retention time at $12.0 \mathrm{~min}$ ) are very likely novel GMs produced by the strain XY-FW47 (see Figure S10). As new analogs may provide more selectivity or low toxicity, it is worth isolating these potential new GMs. Consequently, this bacterial strain was chosen to be the target strain for further study. The 16S rRNA gene sequence of strain XY-FW47 was deposited in GenBank with the accession number MF664376. 


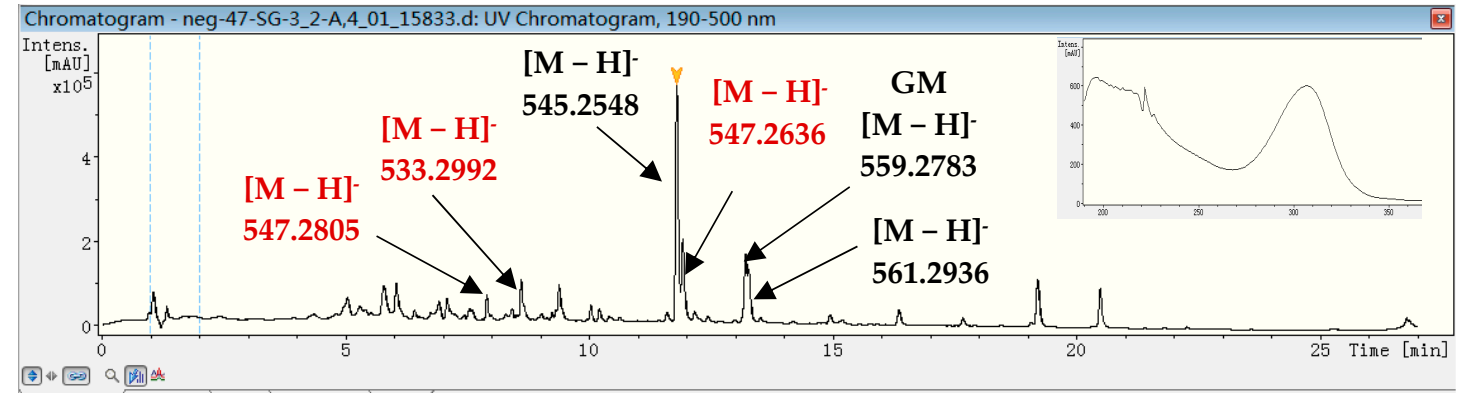

Figure 5. UPLC-MS analysis and UV spectra of the crude extract of XY-FW47: (1) compounds with HR-ESI-MS [M - H] ${ }^{-}$547.2805, 533.2992 and 547.2636 in red are very likely novel GMs (highlighted by red color); and (2) compounds with HR-ESI-MS [M - H] ${ }^{-} 545.2548,559.2783$ and 561.2936 in black show to be known 17-O-demethylgeldanamycin, GM and 4,5-dihydrogeldanamycin (highlighted by black color).

\subsection{Structural Elucidation of the Isolated Compounds}

In total, four compounds were isolated and identified from strain XY-FW47. Compound 1 was isolated as a yellow amorphous powder. The molecular formula of Compound $\mathbf{1}$ was established as $\mathrm{C}_{28} \mathrm{H}_{40} \mathrm{~N}_{2} \mathrm{O}_{9}$ by HR-ESI-MS $\left.(m / z 547.2636 \text {, [M }-\mathrm{H}]^{-}\right)$, with 10 degrees of unsaturation. The ${ }^{13} \mathrm{C}$ and DEPT NMR spectra showed 28 carbon signals (Table 4), which were assigned with the assistance of the distortionless enhancement by polarization transfer (DEPT) spectrum to six methyls, four methylenes, seven methines, and nine quaternary carbons. The signals of ${ }^{1} \mathrm{H}-\mathrm{NMR}$ spectra also revealed six methyl groups $\left(\delta_{\mathrm{H}} 3.41,3.35,1.91,1.68,0.98\right.$, and 0.96$)$ and four methines.

Table $4 .{ }^{1} \mathrm{H}$ and ${ }^{13} \mathrm{C}$ NMR data for Compound 1 in $\mathrm{CDCl}_{3}$.

\begin{tabular}{cccccc}
\hline Position & $\delta_{\mathbf{C}}$ & $\delta_{\mathbf{H}}(J \mathbf{~ i n ~ H z})$ & Position & $\delta_{\mathbf{C}}$ & $\delta_{\mathbf{H}}(J \mathbf{~ i n ~ H z})$ \\
\hline 1 & $168.3, \mathrm{C}$ & & 16 & $117.2, \mathrm{C}$ & \\
2 & $133.1, \mathrm{C}$ & & 17 & $152.8, \mathrm{C}$ & \\
3 & $138.4, \mathrm{CH}$ & $6.25, \mathrm{t}(6.7)$ & 18 & $183.0, \mathrm{C}$ & \\
4 & $24.4, \mathrm{CH}_{2}$ & $2.42, \mathrm{~m}$ & 19 & $107.4, \mathrm{CH}$ & $7.28, \mathrm{~s}$ \\
5 & $29.6, \mathrm{CH}_{2}$ & $1.77, \mathrm{~m}$ & 20 & $140.8, \mathrm{C}$ & \\
6 & $80.9, \mathrm{CH}$ & $3.37, \mathrm{~m}$ & 21 & $184.3, \mathrm{C}$ & \\
7 & $80.3, \mathrm{CH}$ & $5.18, \mathrm{~d}(4.2)$ & $\mathrm{NH}$ & & $8.99, \mathrm{~s}$ \\
8 & $131.0, \mathrm{C}$ & & $22-\mathrm{CH}_{3}$ & $12.3, \mathrm{CH}_{3}$ & $1.91, \mathrm{~s}$ \\
9 & $133.8, \mathrm{CH}$ & $5.68, \mathrm{~d}(9.6)$ & $23-\mathrm{OCH}_{3}$ & $59.0, \mathrm{CH}_{3}$ & $3.41, \mathrm{~s}$ \\
10 & $32.5, \mathrm{C}$ & $2.77, \mathrm{~m}$ & $24-\mathrm{OCONH}_{2}$ & $156.1, \mathrm{C}$ & \\
11 & $73.3, \mathrm{CH}$ & $3.58, \mathrm{~d}(7.8)$ & $25-\mathrm{CH}_{3}$ & $12.5, \mathrm{CH}_{3}$ & $1.68, \mathrm{~s}$ \\
12 & $82.5, \mathrm{CH}$ & $3.38, \mathrm{~m}$ & $26-\mathrm{CH}_{3}$ & $12.7, \mathrm{CH}_{3}$ & $0.96, \mathrm{~d}(7.5)$ \\
13 & $34.9, \mathrm{CH}$ & $1.73, \mathrm{~m}$ & $27-\mathrm{OCH}_{3}$ & $57, \mathrm{CH}_{3}$ & $3.35, \mathrm{~s}$ \\
14 & $28.3, \mathrm{CH}$ & $1.75, \mathrm{~m}$ & $28-\mathrm{CH}_{3}$ & $22.6, \mathrm{CH}_{3}$ & $0.98, \mathrm{~d}(7.5)$ \\
15 & $32.0, \mathrm{CH}$ & $2.40, \mathrm{~m} 2.48, \mathrm{dd}$ & & & \\
\hline
\end{tabular}

The gross structure of Compound 1 and all of the ${ }^{1} \mathrm{H}$ and ${ }^{13} \mathrm{C}$ NMR data associated with the molecule were determined by $2 \mathrm{D}$ NMR studies, including ${ }^{1} \mathrm{H}^{1}{ }^{1} \mathrm{H}$ COSY, $\mathrm{HSQC}$ and $\mathrm{HMBC}$ experiments. The key ${ }^{1} \mathrm{H}^{-1} \mathrm{H}$ COSY correlations of H-3/H $\mathrm{H}_{2}-4 / \mathrm{H}_{2}-5 / \mathrm{H}-6 / \mathrm{H}-7, \mathrm{H}-9 / \mathrm{H}-10 / \mathrm{H}-11 / \mathrm{H}-12 / \mathrm{H}_{2}-13 / \mathrm{H}-14 / \mathrm{H}_{2}-15$, $\mathrm{H}-10 / \mathrm{CH}_{3}-26$ and $\mathrm{H}-14 / \mathrm{CH}_{3}-28$, together with the $\mathrm{HMBC}$ correlations from $\mathrm{CH}_{3}-22$ to $\mathrm{C}-1 / \mathrm{C}-2 / \mathrm{C}-3$, from $\mathrm{OCH}_{3}-23$ to $\mathrm{C}-6$, from $\mathrm{H}-7$ to $\mathrm{C}-8 / \mathrm{C}-9 / \mathrm{C}-24$, from $\mathrm{CH}_{3}-25$ to $\mathrm{C}-8 / \mathrm{C}-9$ and from $\mathrm{CH}_{3}-27$ to $\mathrm{C}-12$, indicated the existence of the ansa ring (see Figure 6), which was similar to 17-O-demethylgeldanamycin [32]. Comparing with the 1D and 2D NMR signals of 17-O-demethylgeldanamycin, the lost of the double bond at C-4 and C-5 in Compound 1, which was replaced by two methenes. The NOSY correlations of 
H-6/H-7/H-12, and H-10/H-11/H-14 indicated the absolute configuration of Compound 1 that was also consistent with 17-O-demethylgeldanamycin. Thus, the structure of Compound 1 was identified.

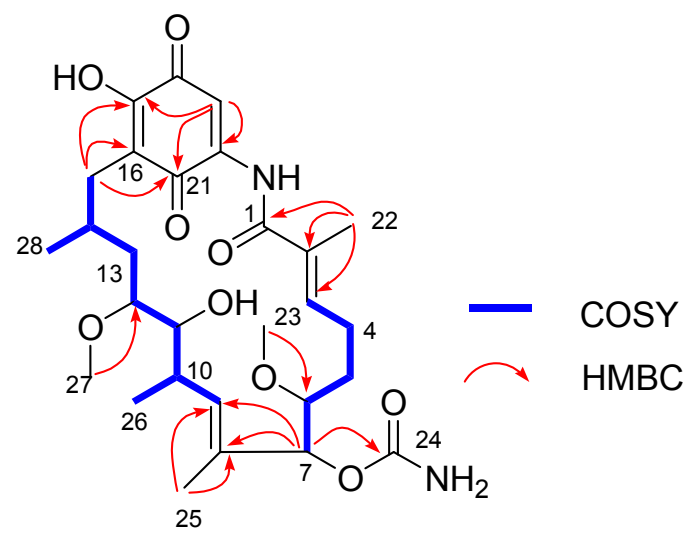

Figure 6. Key COSY and HMBC correlations of Compound 1.

The structures of Compounds $\mathbf{2 - 4}$ were identified as 17-O-demethylgeldanamycin, geldanamycin and 4,5-dihydrogeldanamycin, respectively, by the NMR and UPLC-MS data, and comparing their spectroscopic data with those data reported by Hong et al. and Ni et al. [36,37].

\subsection{Bioactive Evaluation and Structure-Activity Relationship}

The bioactivities (anti-MRSA, anti-HeLa Cell and antifungal) of Compounds 1-4 were evaluated. These compounds showed no activity against MRSA. Compound 3 GM exhibited potent activity against HeLa cells with $\mathrm{EC}_{50} 1.12 \mu \mathrm{g} / \mathrm{mL}$. It also showed antifungal activity against the plant pathogen Setosphaeria turcica with MIC $2.40 \mu \mathrm{g} / \mathrm{mL}$. Previous cytotoxic tests (FRE/erbB-2 tumors) of 4,5-dihydrogeldanamycin (4) revealed much weaker activity than $\mathrm{GM}\left(\mathrm{IC}_{50}=230\right.$ and $70 \mathrm{nM}$, respectively) [38]. Compounds 17-O-demethylgeldanamycin (2) and 17-O-demethylgeldanamycin hydroquinone showed much more cytotoxicity towards normal P19-derived neurons than GM at $1 \mathrm{nM}$ [39]. These data together with the present results of Compound 1-4 indicate that the double bond at C-4,5 and the methoxy group at C-17 position are essential for increasing anti-HeLa cells and anti-S. turcica activities of GMs. As none of the GMs were active against MRSA, the potent anti-MRSA activity of the crude XY-FW47 extract might be contributed by the trace GMs or other types of metabolites which we were not able to isolate. We will need to optimize fermentation conditions of XY-FW47 to obtain enough quantities of these compounds in the future studies.

\section{Materials and Methods}

\subsection{Bacteria Isolation and Identification}

A marine flatworm was collected at depth between 1 and $3 \mathrm{~m}$ intertidal zone of Yung Shue $\mathrm{O}$, Hong Kong $\left(114^{\circ} 21^{\prime}\right.$ E, $\left.22^{\circ} 24^{\prime} \mathrm{N}\right)$ in January 2014, and identified as Paraplanocera sp. based on $18 \mathrm{~S}$ rRNA gene sequencing (1260 bp). The bacterial isolation method was in accordance with the method described by $\mathrm{Xu}$ et al. [15] using modified BD Difco ${ }^{\mathrm{TM}} \mathrm{R} 2 \mathrm{~A}$ agar (adding $17 \mathrm{~g} / \mathrm{L}$ seasalt). The $16 \mathrm{~S}$ rRNA gene sequence of the isolations were determined by PCR using universal primers 27F and 1492R, then the isolates were identified by the blast program in the NCBI database.

\subsection{Bacteria Fermentation}

Small scale fermentation of the cultured bacteria was carried out as follows: seed cultures of the strain were collected in $50 \mathrm{~mL}$ Falcon centrifuge tubes, with each containing $15 \mathrm{~mL}$ of SGTYP medium with sea salts $(5.0 \mathrm{~g}$ soluble starch, $5.0 \mathrm{~g}$ glucose, $1.0 \mathrm{~g}$ tryptone, $1.0 \mathrm{~g}$ yeast extract, $1.0 \mathrm{~g}$ peptone, 
$17.0 \mathrm{~g}$ sea salts per litre, $\mathrm{pH} 7.6 \pm 0.2)$. Then fresh inoculum was inoculated in $250 \mathrm{~mL}$ flasks with each containing $80 \mathrm{~mL}$ of SGTYP medium with sea salts ( $5.0 \mathrm{~g}$ soluble starch, $5.0 \mathrm{~g}$ glucose, $1.0 \mathrm{~g}$ tryptone, $1.0 \mathrm{~g}$ yeast extract, $1.0 \mathrm{~g}$ peptone, $17.0 \mathrm{~g}$ sea salts per litre, $\mathrm{pH} 7.6 \pm 0.2$ ). The flasks were incubated at $28{ }^{\circ} \mathrm{C}$ for 5 days before harvesting. The fermentation broth was extracted with ethyl acetate (EA) three times of the total volume $(1: 3 v / v)$. The EA crude extract of the bacterial fermentation broth was obtained and prepared as $50 \mathrm{mg} / \mathrm{mL}$ stock solution in DMSO for testing.

\subsection{Bioactive and Chemical Screening}

The pathogen MRSA ATCC43300 was incubated in LB broth (10 g tryptone, $5 \mathrm{~g}$ yeast extract and $10 \mathrm{~g} \mathrm{NaCl}$ per liter) at $28{ }^{\circ} \mathrm{C}$ for $12 \mathrm{~h}$ and then diluted 5000 times with fresh LB broth. The tested samples $(2 \mu \mathrm{L})$ were added to each well of 24 -well plates with $1 \mathrm{~mL}$ of the diluted pathogen solution. The pathogen was then incubated at $28^{\circ} \mathrm{C}$ and the optical density at $600 \mathrm{~nm}$ was measured $24 \mathrm{~h}$ after inoculation with vancomycin $(50 \mu \mathrm{g} / \mathrm{mL})$ as positive controls. The cytotoxic assays were performed using the method described by Li et al. [40]. HeLa cells were inoculated and incubated in 24-well plates for $12 \mathrm{~h}$ before adding the tested samples. After incubation for $48 \mathrm{~h}$, the CCK method was used to assay the cell viability. Three biological replicates were carried out for each sample and each bioassay experiment was repeated three times.

The ESI-TOF and mass spectra of the isolates were acquired from a UPLC-TOF-MS system (ultra-performance liquid chromatography-time of fly-mass spectrometry) using a Bruker microTOF-q II (Bruker Daltonics GmbH, Bremen, Germany) mass spectrometer coupled to a Waters ACQUITY UPLC system (Waters, London, UK).

\subsection{Extraction and Compounds Isolation}

Large scale fermentation (50 L) and the extraction of XY-FW47 were obtained as the described method of small scale. The EA crude extract of XY-FW47 was separated by reverse phase C18 chromatography with water and methanol solvent mixtures of $\mathrm{H}_{2} \mathrm{O}-\mathrm{MeOH}(7: 3), \mathrm{H}_{2} \mathrm{O}-\mathrm{MeOH}(5: 5)$, $\mathrm{H}_{2} \mathrm{O}-\mathrm{MeOH}(3: 7), \mathrm{H}_{2} \mathrm{O}-\mathrm{MeOH}(1: 9)$, and $100 \% \mathrm{MeOH}$. The fractions of $\mathrm{H}_{2} \mathrm{O}-\mathrm{MeOH}(3: 7, v / v)$ was evaporated and labeled Fraction (Fr.) $70 \%$. The fraction was subjected to Sephadex LH-20 by mixtures of chloroform/methanol (1:1) yielding 16 fractions and marked Fr.70\%-1 to Fr.70\%-16. Then, Fr.70\%-10 to $\mathrm{Fr} .70 \%-14$ were purified by the elution of $\mathrm{MeCN}-\mathrm{H}_{2} \mathrm{O}(70: 30,(v / v)$, flow rate: $2 \mathrm{~mL} / \mathrm{min})$ through the semi-preparative HPLC (Waters, Parsippany, NJ, USA) using analytical and semi-preparative reverse-phase phenomenex biphenyl columns $(5 \mu \mathrm{m}, 250 \times 4.6 \mathrm{~mm}$ and $5 \mu \mathrm{m}, 250 \times 10 \mathrm{~mm}$ in size), and finally afforded pure Compounds $1(2.6 \mathrm{mg}), 2(12 \mathrm{mg}), 3(7 \mathrm{mg})$ and $4(1 \mathrm{mg})$ at a retention time of $24.0 \mathrm{~min}, 25.0 \mathrm{~min}, 26.0 \mathrm{~min}$ and $27.4 \mathrm{~min}$, respectively. The further ${ }^{1} \mathrm{H},{ }^{13} \mathrm{C}$ and $2 \mathrm{D}$ NMR spectral data were determined on a Bruker DRX $600 \mathrm{MHz}$ NMR Spectrometers.

4,5-Dihydro-17-O-demethylgeldanamycin (1): yellow amorphous powder; $[\alpha]_{\mathrm{D}}^{25}+42.0^{\circ}(c) 0.18$, $\mathrm{CHCl}_{3}$ ); $\mathrm{UV}(\mathrm{MeOH}) \lambda_{\max } 305 \mathrm{~nm}$, HR-ESI-MS $m / z 547.2636[\mathrm{M}-\mathrm{H}]^{-}\left(\right.$calcs for $\mathrm{C}_{28} \mathrm{H}_{40} \mathrm{~N}_{2} \mathrm{O}_{9}$ 547.2656); ${ }^{1} \mathrm{H}$ and ${ }^{13} \mathrm{C}$ NMR data, see Table 4.

\subsection{Bioactive Assays}

The tests of Compounds 1-4 against MRSA ATCC43300 were determined as previously described. The antifungal activities against three plant pathogens (Setosphaeria turcica, Bipolaris maydis and Altemaria solani) were conducted on BD Difco ${ }^{\mathrm{TM}}$ Potato Dextrose Agar at $28^{\circ} \mathrm{C}$ for $24 \mathrm{~h}$. A series of two-fold dilution of tested samples was made with either LB broth or Potato Dextrose Broth in 24-well plates. The antibacterial tests were checked as the method described in the Section 3.3. The antifungal tests were performed at $28{ }^{\circ} \mathrm{C}$ for $24 \mathrm{~h}$, and inhibition of $\geq 95 \%$ of the growth was observed by stereo microscope.

The cytotoxic tests were measured by using the previous method. Compounds 1-4 were prepared as $50 \mathrm{mg} / \mathrm{mL}$ in DMSO, and a series of two-fold dilution was made with the assayed media. After $48 \mathrm{~h}$ of incubation, the cytotoxicities were assayed by the CCK method. 


\section{Conclusions}

This study firstly explored biological and chemical diversity of bacteria associated with the marine flatworm Paraplanocera sp. A total of 141 strains of bacteria were isolated including 45 strains of actinomycetes and 96 strains of other bacteria. Among them, there were three novel strains, suggesting that a rich biodiversity of bacteria may be associated with marine flatworms. The isolation and identification results of these bacteria indicated biological diversity and novelty of bacteria derived from this marine flatworm. One new GM analog (1) and three known GMs (2-4) were obtained from Streptomyces sp. XY-FW47. GM (3) showed potent bioactivity against HeLa cells with EC ${ }_{50} 1.12 \mu \mathrm{g} / \mathrm{mL}$ and against plant fungal pathogen Setosphaeria turcica with MIC $2.40 \mu \mathrm{g} / \mathrm{mL}$. Preliminary discussion of SAR suggested that the existence of C-17 methoxy group and C-4,5 double bond might increase the bioactivities of GMs. Our study has provided new insights into the bacteria associated with marine flatworms.

Supplementary Materials: The following are available online at www.mdpi.com/1660-3397/15/9/281/S1.

Acknowledgments: This work was financially supported by grants from the National Natural Science Foundation of China (No. 41576146), Natural Science Foundation of Guangdong Province (No. 2017A030313227), Seed Funding from Scientific and Technical Innovation Council of Shenzhen Government (Nos. 827000041 and 827000012) and Innovation program of Shenzhen (No. JCYJ20160428181415376).

Author Contributions: Ying $\mathrm{Xu}$ and Kai-Ling Wang designed the experiments; Hui-Na Lin performed the experiments; Hui-Na Lin, Ze-Hong Wu, Ren-Mao Tian and Guo-Zhu Liu analyzed the data; and Hui-Na Lin and Kai-Ling Wang wrote the paper.

Conflicts of Interest: The authors declare no conflict of interest.

\section{References}

1. Rawlinson, K.A. The diversity, development and evolution of polyclad flatworm larvae. Evodevo 2014, 5, 9. [CrossRef] [PubMed]

2. Pfister, D.; Mulder, K.D.; Philipp, I.; Kuales, G.; Hrouda, M.; Eichberger, P.; Borgonie, G.; Hartenstein, V.; Ladurner, P. The exceptional stem cell system of Macrostomum lignano: Screening for gene expression and studying cell proliferation by hydroxyurea treatment and irradiation. Front. Zool. 2007, 4, 9. [CrossRef] [PubMed]

3. Mouton, S.; Willemsa, M.; Braeckmanb, B.P.; Eggerc, B.; Ladurnerc, P.; Schärerd, L.; Borgoniea, G. The free-living flatworm Macrostomum lignano: A new model organism for ageing research. Exp. Gerontol. 2009, 44, 243-249. [CrossRef] [PubMed]

4. Lengerer, B.; Pjeta, R.; Wunderer, J.; Rodrigues, M.; Arbore, R.; Schärer, L.; Berezikov, E.; Hess, M.W.; Pfaller, K.; Egger, B.; et al. Biological adhesion of the flatworm Macrostomum lignano relies on a duo-gland system and is mediated by a cell type-specific intermediate filament protein. Front. Zool. 2014, 11, 12. [CrossRef] [PubMed]

5. Rivera-Ingraham, G.A.; Nommick, A.; Blondeau-Bidet, E.; Ladurner, P.; Lignot, J.H. Salinity stress from the perspective of the energy-redox axis: Lessons from a marine intertidal flatworm. Redox Biol. 2016, 10, 3-64. [CrossRef] [PubMed]

6. Rivera-Ingraham, G.A.; Bickmeyer, U.; Abele, D. The physiological response of the marine platyhelminth Macrostomum lignano to different environmental oxygen concentrations. J. Exp. Biol. 2013, 216, 2741-2751. [CrossRef] [PubMed]

7. Pawlik, J.R. Marine invertebrate chemical defenses. Chem. Rev. 1993, 5, 1911-1922. [CrossRef]

8. Holmström, C.; Kjelleberg, S. Marine Pseudoalteromonas species are associated with higher organisms and produce biologically active extracellular agents. FEMS Microbiol. Ecol. 1999, 30, 285-293. [CrossRef]

9. Bernan, V.S.; Greensten, M.; Maiese, W.M. Marine microorganisms as a source of new natural products. Adv. Appl. Microbiol. 1997, 43, 57-90. [PubMed]

10. Fenical, W. Chemical studies of marine bacteria: Developing a new resource. Chem. Rev. 1993, 93, 1673-1682. [CrossRef] 
11. Tanu, M.B.; Mahmud, Y.; Arakawa, O.; Takatani, T.; Kajihara, H.; Kawatsu, K.; Hamano, Y.; Asakawa, M.; Miyazawa, K.; Noguchi, T. Immunoenzymatic visualization of tetrodotoxin (TTX) in Cephalothrix species (Nemertea: Anopla: Palaeonemertea: Cephalotrichidae) and Planocera reticulata (Platyhelminthes: Turbellaria: Polycladida: Planoceridae). Toxicon 2004, 41, 515-520. [CrossRef] [PubMed]

12. Yamada, R.; Tsunashima, T.; Takei, M.; Sato, T.; Wajima, Y.; Kawase, M.; Oshikiri, S.; Kajitani, Y.; Kosoba, K.; Ueda, H.; et al. Seasonal changes in the Tetrodotoxin content of the flatworm Planocera multitentaculata. Mar. Drugs 2017, 15, 56. [CrossRef] [PubMed]

13. Ritson-Williams, R.; Yotsu-Yamashita, M.; Paul, V.J. Ecological functions of tetrodotoxin in a deadly polyclad flatworm. Proc. Natl. Acad. Sci. USA 2006, 103, 3176-3179. [CrossRef] [PubMed]

14. Gruber-Vodicka, H.R.; Dirks, U.; Leisch, N. Paracatenula, an ancient symbiosis between thiotrophic Alphaproteobacteria and catenulid flatworms. Proc. Natl. Acad. Sci. USA 2011, 108, 12078-12083. [CrossRef] [PubMed]

15. Xu, Y.; Li, Q.; Tian, R.M.; Lai, Q.L.; Zhang, Y. Pseudovibrio hongkongensis sp. nov., isolated from a marine flatworm. Antonie Van Leeuwenhoek 2015, 108, 127-132. [CrossRef] [PubMed]

16. Zhang, Y.; Li, Q.; Tian, R.M.; Lai, Q.L.; Xu, Y. Pseudovibrio stylochi sp. nov., isolated from a marine flatworm. Int. J. Syst. Evolut. Microbiol. 2016, 66, 2025-2029. [CrossRef] [PubMed]

17. Lin, H.N.; Wang, Y.; Huang, J.M.; Lai, Q.L.; Xu, Y. Deinococcus planocerae sp. nov., isolated from a marine flatworm. Antonie Van Leeuwenhoek 2017, 110, 811-817. [CrossRef] [PubMed]

18. Martín-Durán, J.M.; Egger, B. Developmental diversity in free-living flatworms. Evodevo 2012, 3, 7. [CrossRef] [PubMed]

19. Deboer, C.; Meulman, P.A.; Wnuk, R.J.; Peterson, D.H. Geldanamycin, a new antibiotic. J. Antibiot. 1970, 23, 442-447. [CrossRef] [PubMed]

20. Liu, X.; Li, J.Y.; Ni, S.Y.; Wu, L.Z.; Wang, H.Y.; Lin, L.; He, W.Q.; Wang, Y.G. A pair of sulfur-containing geldanamycin analogs, 19-S-methylgeldanamycin and 4,5-dihydro-19-S-methylgeldanamycin, from Streptomyces hygroscopicus 17997. J. Antibiot. 2011, 64, 519-522. [CrossRef] [PubMed]

21. Fukuyo, Y.; Hunt, C.R.; Horikoshi, N. Geldanamycin and its anti-cancer activities. Cancer Lett. 2010, 290, 24-35. [CrossRef] [PubMed]

22. Garcia-Carbonero, R.; Carnero, A.; Paz-Ares, L. Inhibition of HSP90 molecular chaperones: Moving into the clinic. Lancet Oncol. 2013, 14, e358-e369. [CrossRef]

23. Lian, F.; Lin, D.; Gu, J. Novel research progress of anti-tumor activities of geldanamycin and its derivations. World Notes Antibiot. 2010, 5, 202-206.

24. Li, S.F.; Cui, J.; Lu, X.H.; Zheng, Z.H.; Liu, X.; Ni, S.Y.; Wang, Y.G.; Wu, L.Z. Methanethiol as a catabolite of methionine provides methylthio-Group for chemical formation of 19-S-methylgeldanamycin and 17,19-dimethylthioherbimycin A. J. Antibiot. 2013, 66, 499-503. [CrossRef] [PubMed]

25. Zhang, H.; Sun, G.Z.; Li, X.; Pan, H.Y.; Zhang, Y.S. A New Geldanamycin Analogue from Streptomyces hygroscopicus. Molecules 2010, 15, 1161-1167. [CrossRef] [PubMed]

26. Li, S.F.; Ni, S.Y.; Wu, L.Z.; Li, L.; Jiang, B.Y.; Wang, H.Y.; Sun, G.Z.; Gan, M.L.; Li, J.Y.; He, W.Q.; et al. $19-\left[\left(1^{\prime} S, 4^{\prime} \mathrm{R}\right)-4^{\prime}\right.$-Hydroxy-1'-methoxy-2'-oxopentyl] geldanamycin, a Natural Geldanamycin Analogue from Streptomyces hygroscopicus 17997. J. Nat. Prod. 2013, 76, 969-973. [CrossRef] [PubMed]

27. Bondarev, V.; Richter, M.; Romano, S.; Piel, J.; Schwedt, A.; Schulz-Vogt, H.N. The genus Pseudovibrio contains metabolically versatile bacteria adapted for symbiosis. Environ. Microbiol. 2013, 15, 2095-2113. [CrossRef] [PubMed]

28. Brooks, B.W.; Murray, R.G.E. Nomenclature for "Micrococcus radiodurans" and other radiation-resistant cocci: Deinococcaceae fam. nov. and Deinococcus gen. nov., including five species. Int. J. Syst. Bacteriol. 1981, 31, 353-360. [CrossRef]

29. Meienhofer, J.; Atherton, E. Structure-Activity Relationship in the Actinomycins. Adv. Appl. Microbiol. 1973, 16, 203-300. [PubMed]

30. Sousa, M.F.V.Q.; Lopes, C.E.; Pereira, N., Jr. Development of a bioprocess for the production of actinomycin-D. Braz. J. Chem. Eng. 2002, 19, 277-285. [CrossRef]

31. Sazak, A.; Şahin, N.; Güven, K.; Işık, K.; Goodfellow, M. Streptomyces samsunensis sp. nov., a member of the Streptomyces violaceusniger clade isolated from the rhizosphere of Robinia pseudoacacia. Int. J. Syst. Evolut. Microbiol. 2011, 61, 1309-1314. [CrossRef] [PubMed] 
32. Yin, M.; Lu, T.; Zhao, L.X.; Chen, Y.; Huang, S.X.; Lohman, J.R.; Xu, L.H.; Jiang, C.L.; Shen, B. The missing C-17-O-methyltransferase in geldanamycin biosynthesis. Org. Lett. 2011, 13, 3726-3729. [CrossRef] [PubMed]

33. Zhang, K.; Wu, L.; Lin, L.; He, W.; Sun, G.; Wang, Y. Identification and detection of 4,5-dihydrogeldanamycin produced by Streptomyces hygroscopicus 17997. Chin. J. Antibiot. 2009, 34, 267-271.

34. Buchanan, G.; Regentin, R.; Piagentini, M.; Andreas, R.; Robert, M.; Jorge, L.G.; Peter, J.L. Production of 8-Demethylgeldanamycin and 4,5-Epoxy-8-demethylgeldanamycin from a Recombinant Strain of Streptomyces hygroscopicus. J. Nat. Prod. 2005, 68, 607-610. [CrossRef] [PubMed]

35. Khomsan, S.; Paranee, S.; Somboon, T.; Kannawat, D.; Pranee, R.; Pattama, P. Investigation on antimicrobial agents of the terrestrial Streptomyces sp. BCC71188. Appl. Microbiol. Biotechnol. 2017, 101, 533-543.

36. Hong, Y.S.; Lee, D.; Kim, W.; Jeong, J.K.; Kim, C.G.; Sohng, J.K.; Lee, J.H.; Paik, S.G.; Lee, J.J. Inactivation of the carbamoyltransferase gene refines post-polyketide synthase modification steps in the biosynthesis of the antitumor agent geldanamycin. J. Am. Chem. Soc. 2004, 126, 11142-11143. [CrossRef] [PubMed]

37. Ni, S.; Zhang, K.; Wang, Y.; He, W.; Wang, Y.; He, J.; Wu, L. Analysis of geldanamycin analogues in trace amounts by LC-MS/MS. Chin. J. Biotechnol. 2009, 25, 847-853.

38. Schnur, R.C.; Corman, M.L.; Gallaschun, R.J.; Cooper, B.A.; Dee, M.F.; Doty, J.L.; Mumi, M.L.; DiOrio, C.I.; Barbacci, E.G.; Miller, P.E.; et al. erbB-2 oncogene inhibition by geldanamycin derivatives: Synthesis, mechanism of action, and structure-activity relationships. J. Med. Chem. 1995, 38, 3813-3820. [CrossRef] [PubMed]

39. Tadtong, S.; Meksuriyen, D.; Tanasupawat, S.; Isobe, M.; Suwanboriruxa, K. Geldanamycin derivatives and neuroprotective effect on cultured P19-derived neurons. Bioorg. Med. Chem. Lett. 2007, 17, 2939-2943. [CrossRef] [PubMed]

40. Li, Y.; Xu, Y.; Liu, L.; Han, Z.; Lai, P.Y.; Guo, X.; Zhang, X.; Lin, W.; Qian, P.Y. Five new amicoumacins isolated from a marine-derived bacterium Bacillus subtilis. Mar. Drugs 2012, 10, 319-328. [CrossRef] [PubMed]

(C) 2017 by the authors. Licensee MDPI, Basel, Switzerland. This article is an open access article distributed under the terms and conditions of the Creative Commons Attribution (CC BY) license (http://creativecommons.org/licenses/by/4.0/). 